\title{
Comparison of Ozonation and Evaporation as Treatment Methods of Recycled Water for Bioethanol Fermentation Process
}

\author{
André Fernandes ${ }^{1} \cdot$ Grzegorz Boczkaj $^{1}{ }^{[0} \cdot$ Joanna Glazowska $^{1}$ • \\ Renata Tomczak-Wandzel ${ }^{1,2} \cdot$ Marian Kamiński $^{1}$
}

Received: 23 September 2016 / Accepted: 28 February 2017 / Published online: 14 March 2017

(c) The Author(s) 2017. This article is published with open access at Springerlink.com

\begin{abstract}
The paper compared the performance of the ethanol yield after alcoholic fermentation with samples of rejected (RW) and permeate water (PW), RW and PW treated by oxidation with ozone $\left(\mathrm{O}_{3}\right)(5$ and $15 \mathrm{~min})$ and evaporation, aiming the recirculation back to the bioethanol process. RW and PW were collected after an anaerobic bioreactor (AnBR) used for stillage treatment. Nine types of fermentations were made, where one used $100 \%$ tap water (control) and the remaining used $80 \%$ of recycled water and $20 \%$ of tap water. Comparing with the control (15.68\%), evaporated permeate water and permeate water oxidized for $15 \mathrm{~min}$ achieved the highest and closest ethanol concentrations in $\mathrm{v} / \mathrm{v}$ with 14.68 and $14.08 \%$ respectively. RW and PW had the lowest ethanol results with 8.43 and $8.68 \%$. The studied methods for water treatment are effective to recycle water taking into consideration the ethanol yield, allowing a good possibility of recirculation. Chemical oxygen demand, ammonia nitrogen and phosphate content did not strongly affect the ethanol yield in all samples treated, with similar results. Oxidation was more environmental friendly and cheaper if performed in $5 \mathrm{~min}$. Further research in the monitoring of the fermentation, ethanol quality and in the number of cycles of fermentation with recycled water is needed.
\end{abstract}

Grzegorz Boczkaj

grzegorz.boczkaj@gmail.com

1 Department of Chemical and Process Engineering, Chemical Faculty, Gdansk University of Technology, G. Narutowicza St. 11/12, 80-233 Gdansk, Poland

2 Aquateam COWI AS, Karvesvingen 2, 0579 Oslo, Norway
Keywords Fermentation · Recycling · Waste-water · Waste treatment and waste minimisation - Evaporation . Ozonation

\begin{tabular}{|c|c|}
\hline \multicolumn{2}{|c|}{ Abbreviations } \\
\hline$\$$ & American dollars \\
\hline AnBR & Anaerobic bioreactor \\
\hline BOD & Biological oxygen demand \\
\hline $\mathrm{CF}$ & Control fermentation \\
\hline COD & Chemical oxygen demand \\
\hline $\mathrm{E}^{\circ}$ & Energy potential \\
\hline EPW & Evaporated permeate water \\
\hline ERW & Evaporated rejected water \\
\hline HS-CGC-MS & $\begin{array}{l}\text { Headspace capillary gas chromatography- } \\
\text { mass spectrometry }\end{array}$ \\
\hline $\mathrm{kWh}$ & Kilowatts per hour \\
\hline $\mathrm{N}-\mathrm{NH}_{3}$ & Ammonia nitrogen content \\
\hline $\mathrm{O}_{3}$ & Ozone \\
\hline $\mathrm{PO}_{4}^{3-}$ & Phosphate content \\
\hline PW & Permeate water \\
\hline $\mathrm{PW}_{\mathrm{ox}} 15$ & Permeate water oxidized for $15 \mathrm{~min}$ \\
\hline $\mathrm{PW}_{\mathrm{ox}} 5$ & Permeate water oxidized for $5 \mathrm{~min}$ \\
\hline RW & Rejected water \\
\hline $\mathrm{RW}_{\mathrm{ox}} 15$ & Rejected water oxidized for $15 \mathrm{~min}$ \\
\hline $\mathrm{RW}_{\mathrm{ox}} 5$ & Rejected water oxidized for $5 \mathrm{~min}$ \\
\hline
\end{tabular}

\section{Introduction}

Ethanol is one of the most common and abundant compounds especially in the chemical and food industry. Ethanol is commonly used as a solvent and heating agent, reagent in synthesis and it is used also in, flavoring and medicine. The ethanol is mainly produced by fermentation, where agricultural products like sugarcane, corn, wheat and 
others are used as raw material [1]. There are two methods to produce ethanol, wet-mill and dry-grind process [2-7]. Saccharomyces cerevisiae is the most popular and studied microorganism in alcoholic fermentation. It can produce ethanol concentrations in broth up to $18 \%(\mathrm{v} / \mathrm{v})$, grow and survive within those values and can be compatible with other microorganisms present in the fermentation [8-10]. To obtain ethanol in a purity of 96 and $99 \%$ distillation and dehydration processes can be performed respectively $[2$, $11]$.

Stillage is produced in the bottom of the distillation column, presenting a dark brown color, acidic nature $(\mathrm{pH}$ 4-5) and a temperature between 70 and $80{ }^{\circ} \mathrm{C}$. The presence of phenols and melanoidins are responsible for the dark brown color $[1,11,12]$. Chemical characteristics of the stillage differ, depending on the bioethanol feedstock, including chemical oxygen demand (COD) (15-176 $\mathrm{gO}_{2} / \mathrm{L}$ ), biological oxygen demand (BOD) (7-96 $\mathrm{gO}_{2} / \mathrm{L}$ ), total nitrogen content $(0.2-4.2 \mathrm{~g} / \mathrm{L})$, total phosphate content $(0.2-3.0 \mathrm{~g} / \mathrm{L})$, potassium $(0.9-17.5 \mathrm{~g} / \mathrm{L})$ and sulfate content $(2-6 \mathrm{~g} / \mathrm{L})[12,13]$. Treatments such as aerobic and anaerobic digestion, oxidation, adsorption, coagulation/ flocculation, membrane separation, evaporation can be used to reduce the organic load of the stillage. One of the most popular process is the anaerobic digestion of the stillage. This process removes and reduces the content of COD and BOD, converts half of the COD in biogas and $10 \%$ in sludge $[11,12,14,15]$. It can be successfully operated at high organic loading rates, low nutrient and energy requirements and stabilized sludge production [1, 5-7, 12]. Typical digestates from this type of treatment include among others total COD (around $55 \mathrm{~g} / \mathrm{L}$ ), sulfur based COD (around $10 \mathrm{~g} / \mathrm{L}$ ), nitrogen content $(0.7-2.5 \mathrm{~g} / \mathrm{L}$ ) and phosphate content (1.5-10 g/l) [4-7].

Even though the anaerobic digestion can reduce significantly the organic load of the stillage, but it is not enough effective if the purpose is to use the digestate to recycle it back to the fermentation process. In the recent years several studies were done to obtain a possibility of full recycle the treated water from the stillage, applying a further stages of treatment. This would enable to save water, minimize the waste produced and reduce the impact on the environment. Several technologies were tested and are already implemented in the industry. These technologies can include one stage treatment, namely simple centrifugation of the stillage $[4,16]$. Others attempt to implement combination of treatment technologies like biological-physical process, namely a two stage anaerobic digestion and a centrifugation stage between the two anaerobic digestion stages [7, 17-20]. Furthermore a two-step physical processes, like filtration and evaporation [21] as well as centrifugation and membrane filters [13] were studied. In this paper a biological-chemical and a biological-physical treatment processes are proposed. The use of chemical purification by means of oxidation no additional waste is produced, thus minimizing the impact on the environment when comparing with physical processes.

$\mathrm{O}_{3}$ is a powerful oxidizing agent, with a standard oxidation potential $\left(\mathrm{E}^{\circ}\right)$ equivalent to $2.07 \mathrm{~V}$, and is widely used in wastewater treatment and in treatment of tap water. It can decompose rapidly to free radicals that can instantly react with the organic compounds. The advantages of $\mathrm{O}_{3}$ are high reaction rate, almost a lack of harmful by-products formation and generating oxygen $\left(\mathrm{O}_{2}\right)$ as an end product $[22,23]$. Once present in a basic solution, $\mathrm{O}_{3}$ reacts with $\mathrm{OH}^{-}$producing hydroxyl radicals $\left(\mathrm{E}^{\circ} 2.7 \mathrm{~V}\right)$ which are more reactive than $\mathrm{O}_{3}$ [23-25]. Another advantage of using $\mathrm{O}_{3}$ is the disinfection, i.e. ability to efficiently inactivate microorganisms. Disinfection with $\mathrm{O}_{3}$ is widely used in drinking water treatment and its efficiency depends upon the oxidation time and the concentration of used ozone [22]. An evaporation process is proposed in this paper. The stillage is concentrated into syrup and the condensate, which has a low organic load and no inorganic salts and it can be used in closed cycle in the process $[11,12]$. Evaporation can also inactivate microorganisms by heat and pressure shock. At the end, the collected distillate is free from the microorganisms and solid matter. The disadvantage of this process remains on the fact that no reaction occurs here, only separation, where the syrup has high concentration of organic load that still needs to be treated, which is considered an extra waste to the process.

The goal of this paper was to evaluate the possibility of recycling the treated wastewater to the fermentation process using evaporation or ozonation treatment, taking into account the ethanol yield. With this approach the goal is to reduce to the maximum the residues or wastes generated from stillage treatment and obtain a more environment friendly technologies. The treatment was applied to digester effluents, coming from different streams of an anaerobic digestion, namely rejected water (RW) and permeate water $(\mathrm{PW})$. A comparison between ozonation for 5 and $15 \mathrm{~min}$ and evaporation of RW and PW samples and RW and PW samples without secondary treatment were performed. Chemical properties like $\mathrm{COD}, \mathrm{pH}$, ammonia nitrogen content $\left(\mathrm{N}-\mathrm{NH}_{3}\right)$ and phosphate content $\left(\mathrm{PO}_{4}{ }^{3-}\right)$ were compared in all studied processes. The effect of the chemical properties of all liquid samples on the ethanol yield was also studied.

\section{Materials and Methods}

Fermentation experiments were carried out using different types of water, containing $80 \%$ of recycled water and $20 \%$ of tap water, to determine the ethanol concentration 
in $\mathrm{v} / \mathrm{v}$ and compared with control fermentation. Ethanol yield present in each fermentation was determined by HSCGC-MS. The recycled water used passed by a secondary treatment, to increase the ethanol yield and purity of the digester effluents, i.e. PW and RW. Furthermore the efficiency of each treatment was controlled by $\mathrm{COD}, \mathrm{N}-\mathrm{NH}_{3}$ and $\mathrm{PO}_{4}{ }^{3-}$ removal.

\section{Raw Materials}

Approximately $0.90 \mathrm{dm}^{3}$ of RW and $0.70 \mathrm{dm}^{3}$ of PW were kindly given by Veolia research laboratory (Netherlands). Figure 1 explains the method used in this work and the source of the samples used. The stillage comes from the bottom of the distillation column, where the fermentation broth is fed to produce ethanol which is collected at the top of the column. Afterwards it was first submitted to a centrifugation, where the liquid fraction was submitted to an anaerobic digestion in an Anaerobic Bioreactor (AnBR) coupled with an ultrafiltration equipment. PW was collected from the filtrate stream of the ultrafiltration. RW was collected from the liquid fraction of the centrifugation of the sludge from the AnBR. Both RW and PW can be considered digester effluents throughout this paper.

\section{Evaporation}

Evaporation was performed by a Heidoph Laborota 4000 efficient, vacuum rotary evaporator. A Heidolph 2 condenser was used as a condenser of the distillate. The operational conditions were, stirring at $60 \mathrm{rpm}$, vacuum pressure between 75 and $79 \mathrm{kPa}$ and a temperature between 70 and $73{ }^{\circ} \mathrm{C}$.

\section{Ozonation}

The gravimetric method was chosen as a first step to determine the ozonator efficiency. It was determined using a sodium sulfite solution during a certain period of oxidation time, using the apparatus in Fig. 2. The $\mathrm{O}_{3}$ molecules oxidize sulfite $\left(\mathrm{SO}_{3}{ }^{2-}\right)$ to sulfate $\left(\mathrm{SO}_{4}{ }^{2-}\right)$ which was determined gravimetrically as barium sulfate $\left(\mathrm{BaSO}_{4}\right)$ salt. The flowrate of the streams was calculated to determine the molar flowrate of ozone that came out of the ozonator. Afterwards the oxidation system was prepared so that the ozonator would receive air instead of pure oxygen. The scheme of the oxidation system is presented in Fig. 2. Each flask was stirred by a magnetic spinner. Two flat bottom flasks with a porous frit were used in the oxidation procedures. The two flasks were sealed at top to avoid $\mathrm{O}_{3}$ loss. The flow reducing stream was used to reduce the flowrate to the flasks, which went to the venting system. Experimental procedures determined a flowrate around of $6.60 \mathrm{dm}^{3} / \mathrm{min}$ in the stream leaving the ozonator, $6 \mathrm{dm}^{3} / \mathrm{min}$ to the atmosphere and $0.60 \mathrm{dm}^{3} / \mathrm{min}$ to the experimental flasks. $\mathrm{O}_{3}$ concentration determined was $75 \mathrm{mg} / \mathrm{dm}^{3}$. The ozonator used

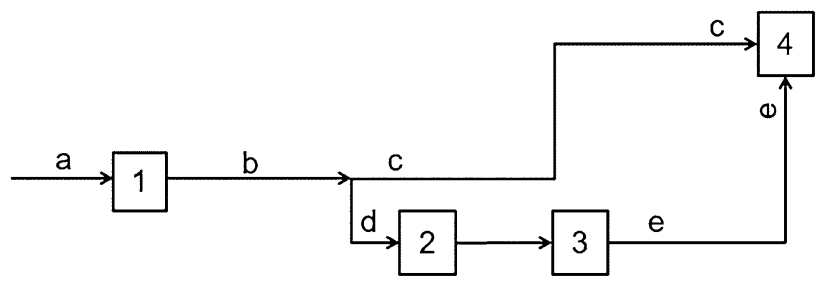

Fig. 2 Scheme of the oxidation system used in the study. 1 ozonator; 2 oxidation flask; 3 oxidation flask; 4 vent; $a$ Air; $b$ stream from ozonator; $c$ flow reducing stream; $d$ flask stream; $e$ stream from oxidation flasks
Fig. 1 Experimental setup of the source of samples used, their treatment and the fermentation performed in this work. Colors of the scheme: Red processes used to obtain the samples used in this paper, green proposed purification process, black fermentation steps. Permeate water (PW); permeate water oxidized for 15 min ( $\left.\mathrm{PW}_{\text {ox }} 15\right)$; permeate water oxidized for $5 \mathrm{~min}$ $\left(\mathrm{PW}_{\mathrm{ox}} 5\right)$; rejected water $(\mathrm{RW})$; rejected water oxidized for $15 \mathrm{~min}\left(\mathrm{RW}_{\mathrm{ox}} 15\right)$; rejected water oxidized for $5 \min \left(\mathrm{RW}_{\mathrm{ox}} 5\right)$. (Color figure online)

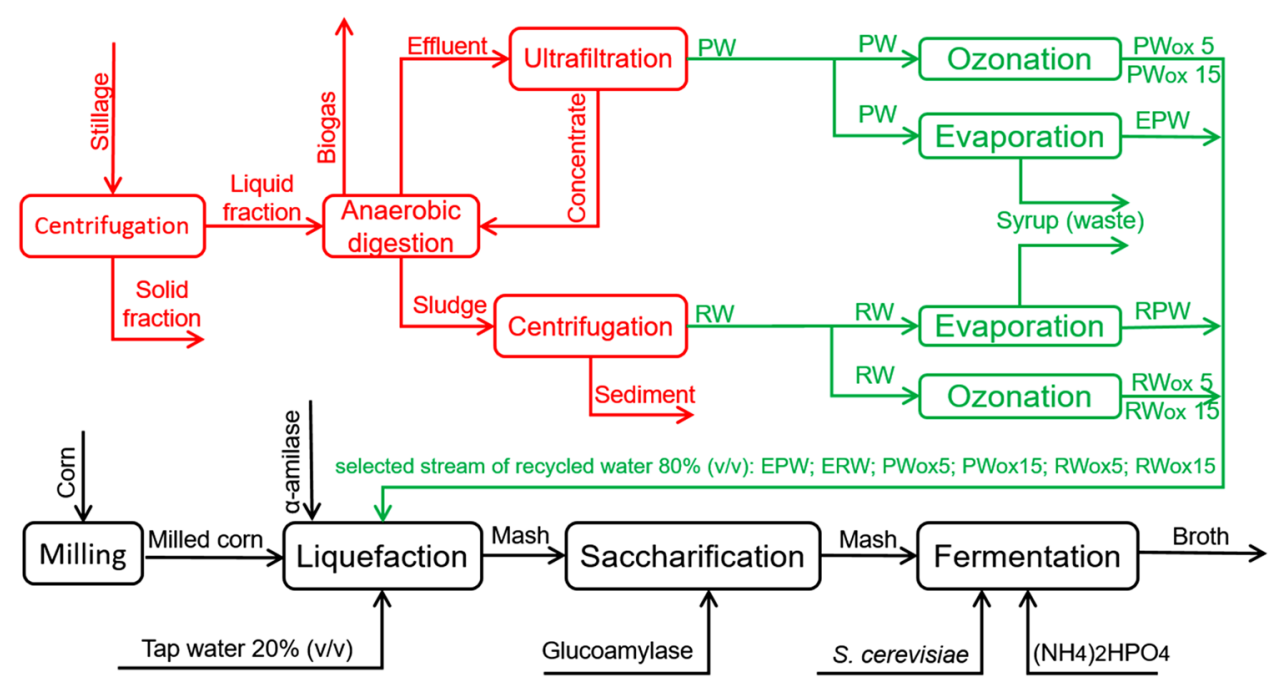


was an ozone generator type Tytan 32. The flowrate of the ozonator was set at $5.0 \mathrm{dm}^{3} / \mathrm{min}$. The pressure of the streams was $196 \mathrm{kPa}$. Approximately $0.10 \mathrm{dm}^{3}$ of RW and PW samples were oxidized in the conditions described above for 5 and 15 min with $\mathrm{O}_{3}$ doses of $1.87 \times 10^{-3}$ and $5.60 \times 10^{-3} \mathrm{~kg}$ respectively. Oxidation was made at the primary $\mathrm{pH}$ of the samples and at room temperature.

\section{Starch Conversion and Fermentation}

The dry-grind process was used to carry out the fermentations done is this work, using corn as feedstock. Figure 1 described the steps to perform the fermentation. $S$. cerevisiae was the microorganism used to perform the fermentations. The preparation of the yeast and starch conversion was carried out in the following steps. The corn was kindly provided by Veolia Company. A $1 \mathrm{~kg}$ of corn was grinded in a Retsch type ZM200 mill. A $0.02 \mathrm{~kg}$ of milled corn was weighted using an analytical balance and transferred to the fermentation flask. A $0.10 \mathrm{dm}^{3}$ of water was added into the flask, where in the control fermentation $(\mathrm{CF})$ only tap water was used. In the rest of the fermentations a mixture of $80 \%$ of recycled water and $20 \%$ of tap water were used. Afterwards the $\mathrm{pH}$ was adjusted to 5.5 with $\mathrm{HCl}(35-38 \%)$ using a Hana type HI8817 $\mathrm{pH}$-meter, $1.0 \times 10^{-4} \mathrm{dm}^{3}$ of $\alpha$-amilase (liquefying enzyme provided by Veolia) was added and the mixture was heated to $85^{\circ} \mathrm{C}$ and mixed for $60 \mathrm{~min} \mathrm{~s}$ in the heater described above. To monitor the starch degradation to simpler sugars an iodine test was performed with Lugol's solution every $15 \mathrm{~min}$. The test was stopped when there was no color change in the solution. Afterwards, the mash was cooled down to $60^{\circ} \mathrm{C}$, the $\mathrm{pH}$ was adjusted to 4.8 with $\mathrm{HCl}(35-38 \%)$ and $1 \times 10^{-4} \mathrm{dm}^{3}$ of glucoamylase (saccharification enzyme provided by Veolia) was added. After 5 and 15 min of adding the enzyme the iodine test was performed. When the mash reached $35^{\circ} \mathrm{C}, 5.0 \times 10^{-4}$ $\mathrm{kg}$ of dry yeast $S$. cerevisiae and $1.0 \times 10^{-4} \mathrm{~kg}$ of Ammonium phosphate dibasic were added. The $\mathrm{pH}$ was adjusted to 4.8 with $\mathrm{HCl} 35-38 \%$ and the fermentation started in a $0.25 \mathrm{dm}^{3}$ round flasks with a flat bottom inside a heater chamber research NCB-65G dryer, at $35^{\circ} \mathrm{C}$ for 2 days without stirring. Liquid samples for ethanol determination were collected at the end of fermentation and filtered by a Millipore hydrophilic filter with a $0.45 \mu \mathrm{m}$ pore diameter. A gas collection system was prepared to control the $\mathrm{CO}_{2}$ production rate during the fermentation. At the end of the airlock of the fermentation flask, a steal capillary was installed in order to collect the gases into two (connected in parallel) $3 \mathrm{dm}^{3}$ tedlar bags immersed in water inside a recipient. A $2.0 \mathrm{dm}^{3}$ beaker collected the water which came out from the recipient (when gas entered in the bags).

\section{Analytical Methods}

The determination of the COD was made by standard cuvette test. A Hach DRB 200 heater was used for mineralization. The analyses were made in duplicate samples. A Hach DR/2000 Spectrometer was used to read the COD values. $\mathrm{N}-\mathrm{NH}_{3}$ was determined by the Nessler method, using the same spectrophotometer. The $\mathrm{PO}_{4}{ }^{3-}$ was also measured by the method 8048 developed by $\mathrm{HACH}$ [26]. The ethanol concentration was analyzed by headspace capillary gas chromatography-mass spectrometry (HS-CGC-MS) [27-29]. The equipment used was a HP gas chromatograph, model 5890 series II and a HP single mass spectrometer quadrupole type, model 5972 A. A two point calibration curve for ethanol was used. The calibration points were 2 and $15 \% \mathrm{v} / \mathrm{v}$. The samples were heated in the chamber at $80^{\circ} \mathrm{C}$ for $45 \mathrm{~min}$. Afterwards $2.0 \times 10^{-4}$ $\mathrm{dm}^{3}$ of the gas phase was sampled by a gastight syringe and injected to the GC for analysis. The software used was the HP ChemStation. Every analysis was made in triplicate. The chromatographic parameters for the ethanol analysis are the following. Initial temperature $35^{\circ} \mathrm{C}$ (5 min isothermal); rate of increasing $10^{\circ} \mathrm{C} / \mathrm{min}$; final temperature $150^{\circ} \mathrm{C}$; gas used $\mathrm{H}_{2}$; flow $1.02 \times 10^{-3} \mathrm{dm}^{3} / \mathrm{min}$; split ratio 20:1; column specifications DB-5ms (Agilent, USA) $60 \mathrm{~m} \times 0.25 \mathrm{~mm} \times 1.40 \mu \mathrm{m}$; injector temperature; $200^{\circ} \mathrm{C}$; detector temperature $200^{\circ} \mathrm{C}$. Using the calibration curve (external standard), concentration of ethanol was determined in percent $(\mathrm{v} / \mathrm{v})$.

\section{Results and Discussion}

The possibility of recycling water from a two stage stillage treatment was evaluated on the basis of the ethanol yield and compared with the CF. Furthermore an economical evaluation was performed on basis of the operational costs of each treatment studied.

\section{Chemical Properties of RW and PW and Treated by $\mathrm{O}_{3}$ and Evaporation}

The samples were analysed for $\mathrm{pH}, \mathrm{COD}, \mathrm{N}-\mathrm{NH}_{3}$ and $\mathrm{PO}_{4}{ }^{3-}$ before and after treatment and their respective removal after treatment are represented in Table 1. The types of water studied and used in fermentations were the RW, PW, evaporated rejected water (ERW), evaporated permeate water (EPW), rejected water oxidized for $5 \mathrm{~min}$ $\left(\mathrm{RW}_{\mathrm{ox}} 5\right)$, rejected water oxidized for $15 \mathrm{~min}\left(\mathrm{RW}_{\mathrm{ox}} 15\right)$, permeate water oxidized for $5 \min \left(\mathrm{PW}_{\mathrm{ox}} 5\right)$ and permeate 
Table 1 Chemical properties of samples studied and their reduction after treatment

\begin{tabular}{lclllllr}
\hline & $\mathrm{COD}\left(\mathrm{mgO}_{2} / \mathrm{L}\right)$ & $\begin{array}{l}\mathrm{COD} \\
\text { removal } \\
(\%)\end{array}$ & $\mathrm{N} / \mathrm{NH}_{3}(\mathrm{mg} / \mathrm{L})$ & $\begin{array}{l}\mathrm{N} / \mathrm{NH}_{3} \\
\text { removal } \\
(\%)\end{array}$ & $\mathrm{PO}_{4}{ }^{3-}(\mathrm{mg} / \mathrm{L})$ & $\mathrm{PO}_{4}{ }^{3-}$ removal $(\%)$ & $\mathrm{pH}$ \\
\hline $\mathrm{RW}$ & $3635 \pm 64$ & - & 364 & - & 1200 & - & 7.5 \\
$\mathrm{PW}$ & $816 \pm 21$ & - & 210 & - & 3740 & - & 7.9 \\
$\mathrm{DRW}$ & $12 \pm 0$ & 99.67 & 194 & 46.70 & 0 & 100.00 & 8.6 \\
$\mathrm{DPW}$ & $18 \pm 0$ & 97.79 & 176 & 16.19 & 0 & 100.00 & 8.1 \\
$\mathrm{RW}_{\text {ox }} 5$ & $3605 \pm 71$ & 0.83 & 275 & 24.45 & 1890 & -57.50 & 7.8 \\
$\mathrm{RW}_{\text {ox }} 15$ & $3260 \pm 35$ & 10.32 & 225 & 38.19 & 1535 & -27.92 & 8.2 \\
$\mathrm{PW}_{\text {ox }} 5$ & $428 \pm 4$ & 47.55 & 193 & 8.10 & 1520 & 59.36 & 8.2 \\
$\mathrm{PW}_{\text {ox }} 15$ & $407 \pm 10$ & 50.12 & 153 & 27.14 & 1340 & & 8.2 \\
\hline
\end{tabular}

$R W$ rejected water, $P W$ permeate water, $E R W$ evaporated rejected water, $E P W$ evaporated permeate water, $R W_{o x} 5$ rejected water oxidized $5 \mathrm{~min}, R W_{o x} 15$ rejected water oxidized $15 \mathrm{~min}, P W_{o x} 5$ permeate water oxidized $5 \mathrm{~min}, P W_{o x} 15$ permeate water oxidized $15 \mathrm{~min}$

Table 2 Determination of the energy costs of each treatment applied in rejected and permeate water (RW and PW)

\begin{tabular}{|c|c|c|c|c|c|c|c|}
\hline $\begin{array}{l}\text { Recycled } \\
\text { water }\end{array}$ & $\begin{array}{l}\text { Equipment } \\
\text { power (W) }\end{array}$ & $\begin{array}{l}\text { Heat of vaporization } \\
(\mathrm{KJ} / \mathrm{kg})\end{array}$ & $\begin{array}{l}\text { Volume } \\
\text { treated }(\mathrm{L})\end{array}$ & $\begin{array}{l}\text { Time of treat- } \\
\text { ment (min) }\end{array}$ & $\begin{array}{l}\text { Energy/volume } \\
\text { treated }(\mathrm{kWh})\end{array}$ & $\begin{array}{l}\text { Energy per } \mathrm{m}^{3} \\
\left(\mathrm{kWh} / \mathrm{m}^{3}\right)\end{array}$ & $\begin{array}{l}\text { Energy cost } \\
\left(\$ / \mathrm{m}^{3}\right)\end{array}$ \\
\hline ERW & 1300 & 2257 & 0.43 & - & 0.34 & 784 & 80 \\
\hline EPW & 1300 & 2257 & 0.415 & - & 0.33 & 784 & 80 \\
\hline $\mathrm{RW}_{\mathrm{ox}} 5$ & 450 & - & 0.1 & 15 & 0.113 & 1125.9 & 114 \\
\hline $\mathrm{RW}_{\mathrm{ox}} 15$ & 450 & - & 0.1 & 5 & 0.038 & 375.3 & 38 \\
\hline $\mathrm{PW}_{\mathrm{ox}} 5$ & 450 & - & 0.1 & 5 & 0.038 & 375.3 & 38 \\
\hline $\mathrm{PW}_{\mathrm{ox}} 15$ & 450 & - & 0.1 & 15 & 0.113 & 1125.9 & 114 \\
\hline
\end{tabular}

$E R W$ evaporated rejected water, $E P W$ evaporated permeate water, $R W_{o x} 5$ rejected water oxidized 5 min, $R W_{o x} 15$ rejected water oxidized 15 min, $P W_{o x} 5$ permeate water oxidized $5 \mathrm{~min}, P W_{o x} 15$ permeate water oxidized $15 \mathrm{~min}$

water oxidized for $15 \min \left(\mathrm{PW}_{\mathrm{ox}} 15\right)$. A standard test method was used in all cases described in this work. In Table 2 the percentage of removal of the treated samples with ozonation and distillation is summarized. All samples of RW and PW treated revealed COD removal, where the ERW and EPW had higher COD removal. Regarding $\mathrm{PO}_{4}{ }^{3-}$, it also decreased in all samples except the $\mathrm{RW}_{\text {ox }} 5$ and $\mathrm{RW}_{\mathrm{ox}} 15$, where it increased 57.5 and $27.92 \%$ respectively when comparing with the RW.

Regarding the EPW and ERW, they were almost completely purified, with total removal of $\mathrm{PO}_{4}{ }^{3-}$, which remained in the syrup. A 97.79 and $99.67 \%$ COD removal and partial removal of $\mathrm{N}-\mathrm{NH}_{3}$ by 16.19 and $46.71 \%$ respectively was achieved. These results suggested a good separation of the organic load from the water.

Analysis of the results revealed that regarding the oxidized rejected water, there was partial removal of $\mathrm{N}-\mathrm{NH}_{3}$ by $24.45 \%$ in $\mathrm{RW}_{\text {ox }} 5$ and $38.19 \%$ in $\mathrm{RW}_{\mathrm{ox}} 15$. Phosphate removal was the opposite of the rest of the treatments with an increase of $57.50 \%$ in $\mathrm{RW}_{\text {ox }} 5$ and $27.92 \%$ in $\mathrm{RW}_{\mathrm{ox}} 15$. A possible explanation can be related to the analysis of the phosphate content, which is related with the dissolved orthophosphate. Since the rejected water had some solid particles, organic phosphate digestion could occur during oxidation. The COD removal was $0.83 \%$ in $\mathrm{RW}_{\mathrm{ox}} 5$ and $10.32 \%$ in $\mathrm{RW}_{\mathrm{ox}} 15$. A possible explanation for such behavior can be related with the nature of the RW, which is more persistent to oxidation. In addition the COD reduction in 5 min of oxidation was $30 \mathrm{mg} / \mathrm{L}$ and in $15 \mathrm{~min}$ was $375 \mathrm{mg} / \mathrm{L}$. The COD removal does not explain the differences in the ethanol yield, but it is clear that longer oxidation results in higher removal of $\mathrm{COD}, \mathrm{N}-\mathrm{NH}_{3}$ and $\mathrm{PO}_{4}{ }^{3-}$.

Regarding the oxidized permeate water, its observable a high COD removal in first 5 min of oxidation, with $47.55 \%$ but after 15 min only an increase of $2.57 \%$ was observable comparing with $5 \mathrm{~min}$ of oxidation to $50.12 \%$. $\mathrm{PO}_{4}{ }^{3-}$ removal was $59.36 \%$ in the $\mathrm{PW}_{\mathrm{ox}} 5$ and $64.17 \%$ in the $\mathrm{PW}_{\text {ox }} 15$. The $\mathrm{N}^{-\mathrm{NH}_{3}}$ removal was $8.10 \%$ in the $\mathrm{PW}_{\text {ox }} 5$ and $27.14 \% \mathrm{PW}_{\text {ox }} 15$. It is clear that longer oxidation time increased the removal rates of $\mathrm{COD}, \mathrm{N}-\mathrm{NH}_{3}$ and phosphate, but the removal was higher in the first minutes of oxidation.

Regarding the time of oxidation in overall higher oxidation time, it increased the removal of COD, $\mathrm{N}^{-\mathrm{NH}_{3}}$ and $\mathrm{PO}_{4}{ }^{3-}$, with only one exception that was the $\mathrm{PO}_{4}{ }^{3-}$ in the RW. 
Comparing the evaporation with oxidation as treatment methods for PW and RW, evaporation revealed by far higher COD and phosphate removal values, with more than 97.5 and $100 \%$ respectively. Regarding $\mathrm{N}^{-\mathrm{NH}_{3}}$ removal, EPW was lower than $\mathrm{PW}_{\mathrm{ox}} 15$ (16 and 27\%) and higher in the ERW comparing with $\mathrm{RW}_{\mathrm{ox}} 15$ (47 and 38\%). Evaporation results in higher removal values and quality of treated water, suggesting a good separation between water and the organic load. However the syrup produced results in additional waste generated, which is highly concentrated in organic compounds. In the oxidation no additional waste is generated, resulting in a more environmental friendly technology [23, 24].

Analysing the $\mathrm{pH}$ of all oxidation processes, it can be said that the $\mathrm{pH}$ was not optimal if the goal was to remove organic load from the water [23, 24]. Since the treated water had to be re-used in fermentation, alkaline $\mathrm{pH}$ would not be a reasonable choice, since the adjustment of the $\mathrm{pH}$ value would be a problem in a close cycle, which would increase the cost of the process. Furthermore the closer the $\mathrm{pH}$ of the recycled water to the $\mathrm{pH}$ of the tap water, the lesser amount of chemicals would be needed to adjust the $\mathrm{pH}$ value. Thus not changing the $\mathrm{pH}$ was the best choice.

\section{Ethanol Yield}

A comparison of the concentration of ethanol in percent $\mathrm{v} / \mathrm{v}$ for of all fermentations performed is presented in Fig. 3, which can be described as the ethanol yield of the fermentation due to the fact that the same final volume of water was obtained after fermentation. The CF (using only tap water) achieved $15.65 \%(\mathrm{v} / \mathrm{v})$ of ethanol concentration very similar to values reported by Wang et al. [3] (15.5\%). $\mathrm{PW}_{\mathrm{ox}} 15$ and ERW had the highest ethanol concentrations, 14.08 and $14.68 \%$ v/v. The $\mathrm{RW}_{\mathrm{ox}} 15, \mathrm{ERW}, \mathrm{PW}_{\mathrm{ox}} 5$ and $\mathrm{RW}_{\mathrm{ox}} 5$ obtained reasonable ethanol concentrations $\mathrm{v} / \mathrm{v}$ by $13.75,12.74,12.81$ and $11.98 \%$ respectively, with values in the range of ethanol concentration in the fermentation broth $[2,3,8]$. It is clear that the recycled treated digester effluents had a twofold increase of the ethanol yield, when comparing with recycled untreated digester effluent (samples RW and PW).

Comparing the $\mathrm{PW}_{\mathrm{ox}} 15$ and $\mathrm{RW}_{\mathrm{ox}} 15$, similar values were found in ethanol concentration (14.08 and $13.75 \%$ respectively). Even though $\mathrm{COD}, \mathrm{PO}_{4}{ }^{3-}$ and $\mathrm{N}-\mathrm{NH}_{3}$ values were higher in $\mathrm{RW}_{\text {ox }}$ than in $\mathrm{PW}_{\mathrm{ox}}$ (8.4 times in COD; 1.5 times in $\mathrm{N} / \mathrm{NH}_{3} ; 1.15$ times in phosphate), it did not seemed to make a strong effect on the ethanol yield. Thus the ethanol yield is not dependent on the COD, N-NH 3 and $\mathrm{PO}_{4}{ }^{3-}$ content in the range of concentrations reported in this paper.

Comparing the RW and PW oxidized for 5 and $15 \mathrm{~min}$, the ethanol yield increased for samples collected after 5-15 min of oxidation (PW 12.84-14.08\% and RW 11.98 and $13.75 \%$ ) revealing that longer exposure to $\mathrm{O}_{3}$ could enhance the ethanol yield.

The comparison between evaporation and oxidation treatments regarding the ethanol yield as performed. Regarding PW, EPW and $\mathrm{PW}_{\mathrm{ox}} 15$ achieved similar ethanol yields (14.68 and $14.05 \%$ respectively). On the other hand in RW. Even though ERW had higher treatment efficiency, it obtained 1\% lower ethanol yield than $\mathrm{RW}_{\mathrm{ox}} 15$ (12.74 and 13.75\%). Nevertheless the results are not significant different between treatments for PW and RW. The RW and PW had the lowest ethanol concentration in $(\mathrm{v} / \mathrm{v})$ of all fermentations performed with 8.43 and $8.68 \%$ respectively, which was approximately half of ethanol yield for the CF and some treated samples. These results are comparable with values of Gao et al. [7] which obtained $9.5 \%$ (v/v) ethanol concentrations using $90.9 \%$ $(\mathrm{v} / \mathrm{v})$ of the treated water by anaerobic digestion. Likewise Bialas et al. [4] obtained 9.5\% (v/v) ethanol concentration using $75 \%$ of the treated water from a distillation process. Sun et al. [18] used a combination of two-stage UASB treatment on the treatment of stillage and also obtain ethanol concentrations around 10\% using $100 \%$ of treated water. This study proved that the treatment of the digester effluent can increase significantly the ethanol yield to values close to the control fermentation. The combination of biological and physical/chemical treatment of the recycled stillage revealed to be effective in terms of ethanol yield after fermentation.

It is clear that is necessary to study BOD, sugars, microorganisms, acids and by-products during the fermentation, to determine if there are any inhibitions leading to lower ethanol production and consequently ethanol yield. In addition there is a need to conduct several recycle fermentations with the recycled water to check if the accumulation of the chemical parameters discussed here can influence the ethanol yield.

Figure 4 presents the $\mathrm{CO}_{2}$ production rate during the fermentation. The studies revealed that $\mathrm{PW}_{\mathrm{ox}} 15$ had lowest production of $\mathrm{CO}_{2}\left(2.85 \mathrm{dm}^{3}\right)$, even lower than $\mathrm{PW}$ $\left(3 \mathrm{dm}^{3}\right)$. In addition CF had similar values than DPW (3.27 comparing with $3.26 \mathrm{dm}^{3}$ ). These results are not consistent with the ethanol yields described above. This proves that there is no relation between the ethanol yield and the $\mathrm{CO}_{2}$ production. Four phases in the alcoholic fermentation in respect to the $\mathrm{CO}_{2}$ production were observed. The lag phase can be seen between 0 and $2 \mathrm{~h}$ of fermentation, the exponential phase of $\mathrm{CO}_{2}$ production was between 2 and $8 \mathrm{~h}$ of fermentation, and from 8 to approximately $20 \mathrm{~h}$ of fermentation the $\mathrm{CO}_{2}$ production rate decreased significantly, where differences started to be noted. After $20 \mathrm{~h}$ of fermentation the $\mathrm{CO}_{2}$ production rate decreased to values close to zero, where this period can be considered as the stationary phase. 
Fig. 3 Comparison of the ethanol concentrations $\mathrm{v} / \mathrm{v}$ of every fermentations performed

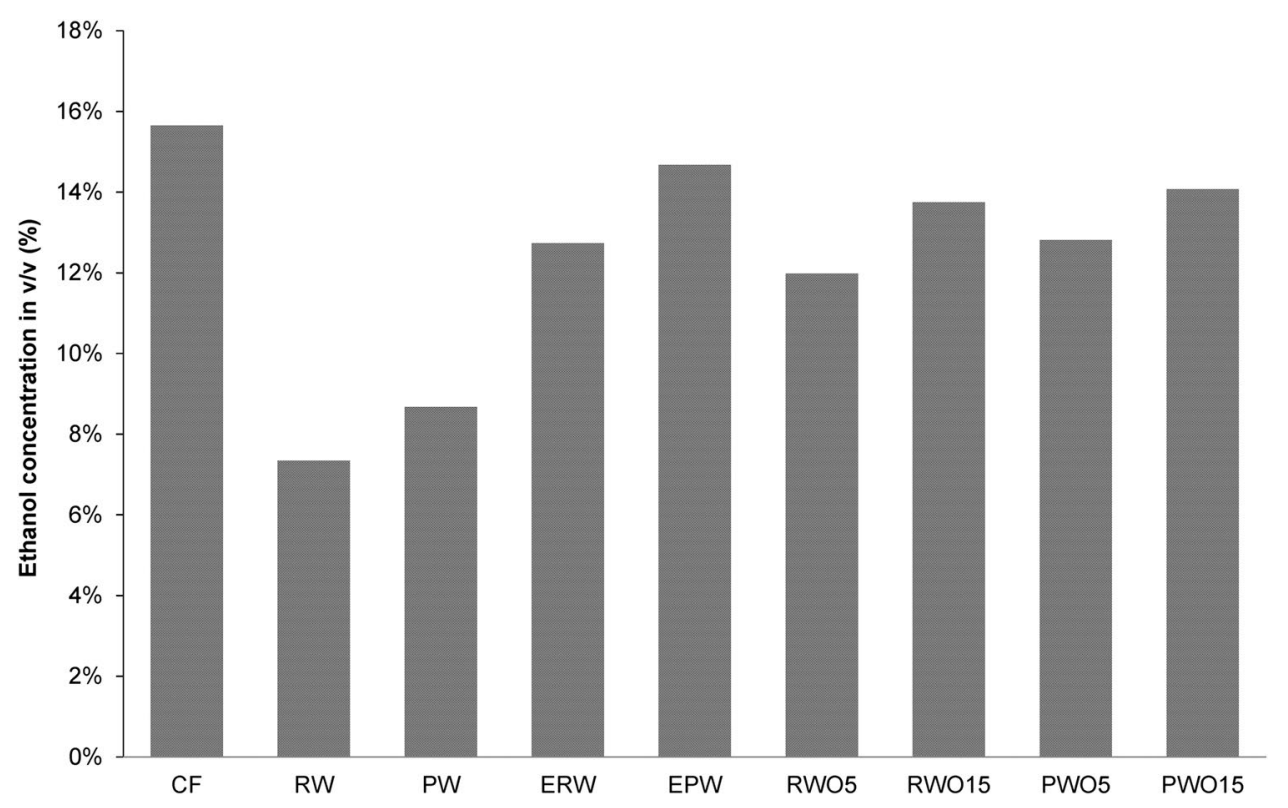

\section{Economical Evaluation}

An economical evaluation was performed to determine which of the studied technologies is cheaper to implement in a real case scenario. The approach used was the determination of the operational costs. Since no chemicals are used in evaporation or ozonation, the operational costs are based only in the energy costs. The cost was determine for the treatment of $1 \mathrm{~m}^{3}$ of RW and PW. The power used in kilowatts per hour $(\mathrm{kWh})$ was first determine for the volume of RW and PW treated in this work. In the case of ozonation it was done by multiplying the equipment power by the time of treatment. In evaporation it was determined by multiplying the mass of water treated by the heat of evaporation of water at atmospheric pressure and temperature. It was omitted the influence of salts, and particles on this value. It was considered an efficiency of $80 \%$ in the evaporation. Afterwards an energy consumption followed by the energy cost to treat $1 \mathrm{~m}^{3}$ of RW and PW was determined. In this work, the power of the ozonator was $450 \mathrm{~W}$. The time of treatment was 5 and $15 \mathrm{~min}$ in the ozonation. The volume of RW and PW used is presented in Table 2. The heat of vaporization of water is $2257 \mathrm{KJ} / \mathrm{kg}$. The energy cost in Poland for industrial clients is 0.1015 American dollars (\$) per kWh (Fig. 4).
Fig. $4 \mathrm{CO}_{2}$ production rate during the fermentations. $Y$ axis gives the volume of $\mathrm{CO}_{2}$ produced in liters and $X$ axis the time of fermentation in hours. Solid blue triangles control fermentation (CF); Solid red squares permeate water oxidized 15 min ( $\left.\mathrm{PW}_{\mathrm{ox}} 15\right)$; Solid orange circles evaporated permeate water (EPW); Solid purple diamonds permeate water (PW). (Color figure online)

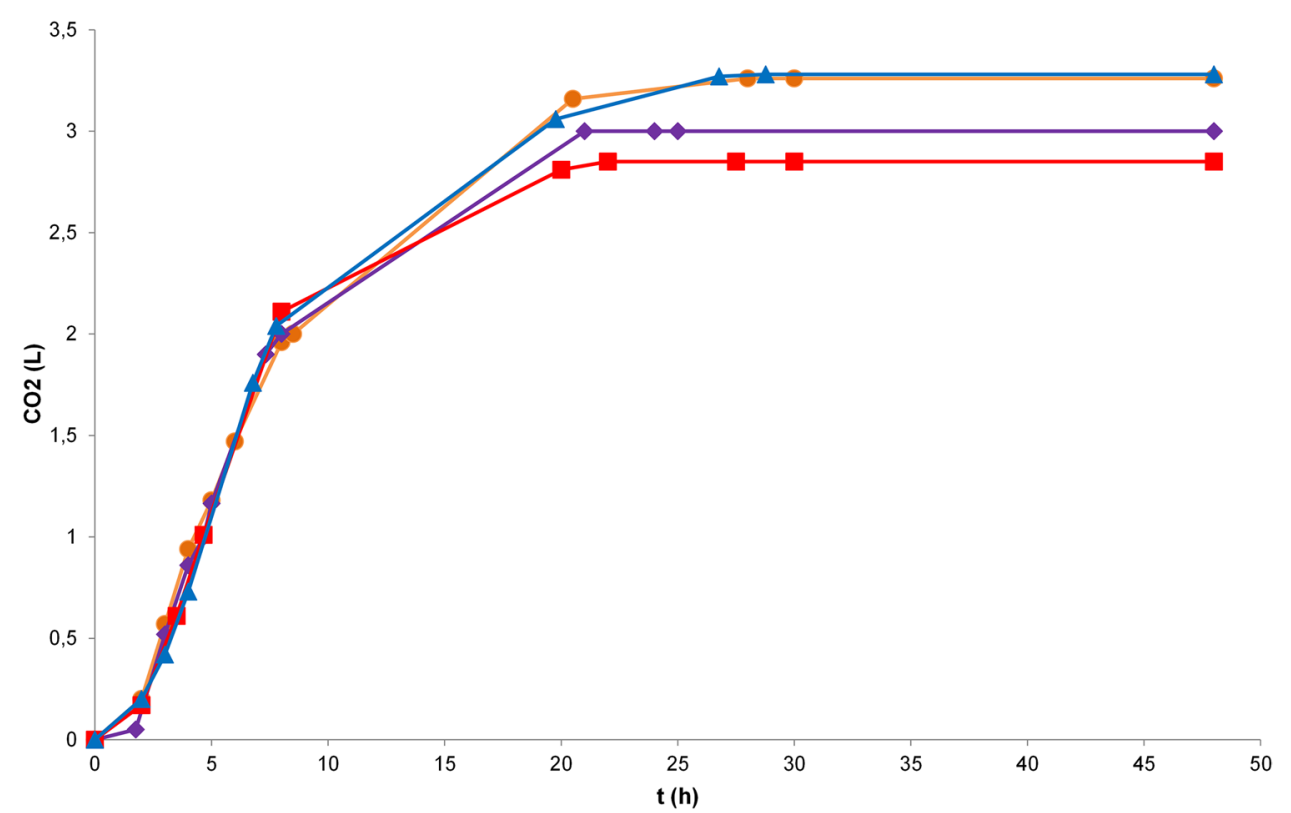


Looking to Table 2 it is proved that oxidation treatment is the cheapest with a value of $38 \$ / \mathrm{m}^{3}$, but if the treatment is extended to $15 \mathrm{~min}$ the scenario changes and oxidation is more expensive with $114 \$ / \mathrm{m}^{3}$ comparing with $80 \$ / \mathrm{m}^{3}$ in evaporation technology. Taking this into account evaporation and oxidation during $15 \mathrm{~min}$, it can be said that evaporation is the most economical choice, in basis of energy costs.

\section{Conclusions}

The aim of this study was to compare an evaporation and oxidation as a final stage of stillage treatment to recycle the treated water and use it in the ethanol process, namely the fermentation process. This comparison was made by analyzing the ethanol yield of all samples, with additional analysis of chemical parameters like $\mathrm{COD}, \mathrm{N}-\mathrm{HH}_{3}$ and $\mathrm{PO}_{4}{ }^{3-}$ content to check their influence in the ethanol yield. Longer oxidation time revealed higher ethanol yields and removal values of $\mathrm{COD}, \mathrm{N}-\mathrm{HH}_{3}$ and $\mathrm{PO}_{4}{ }^{3-}$ content, generating higher quality of treated WW. In overall evaporation achieved higher removal values in the parameters studied, generating higher quality of treated water. Nevertheless it produces additional waste with high content of phosphate, $\mathrm{COD}$ and $\mathrm{N}-\mathrm{NH}_{3}$ which still needs treatment.

Regarding the efficiency of the fermentations, in respect to the ethanol yield, the results achieved were acceptable and close to the levels of the control fermentation. The chemical treatment after anaerobic treatment reveals to be a cleaner technology comparing with evaporation. In addition oxidation in $5 \mathrm{~min}$ revealed to be cheaper than evaporation in terms of operational costs, but in $15 \mathrm{~min}$ is more expensive than evaporation. Moreover all treated PW and RW and CF were within the range of normal ethanol yields $[2,3,8]$, with PW having slightly higher values than treated RW. The COD, $\mathrm{N}-\mathrm{HH}_{3}$ and $\mathrm{PO}_{4}{ }^{3-}$ content did not affect strongly the ethanol yields in all samples treated, proving that there is no connection between them. This conclusion is limited to the concentration level of this parameters and cannot be generalized. Thus the results are positive and enable a good possibility of recirculation of treated PW and RW in the alcoholic fermentation process and minimizing the waste produced in a bioethanol facility.

Nevertheless further research is needed to determine the main inhibitors which made the RW and PW untreated achieved only approximately half of the ethanol concentration in $(\mathrm{v} / \mathrm{v})$ in CF. Likewise fermentation parameters and by-products should also be monitored. In addition the monitoring of the quality of ethanol produced by the recycled water should be performed. The number of cycles of fermentation plays an important role regarding the implementation in industrial facility. This aspect needs further research to understand if the number of cycles of fermentation affects the ethanol production and quality. The results of this paper were used for patent registration of the technology of closed cycle in ethanol fermentation [30].

Acknowledgements The authors would like to thank the Veolia, especially dr Bugusław Buczak (PhD. Eng.; Veolia Water), and Komers International for their cooperation on this project. The authors would like to thank also Mr. Wiesław Szyrszyng (Eng.) for technical help during the studies. This paper has been in part realized in the scope of project entitled Studies of alkaline hydrolysis of lignocellulosic biomass and conversion conditions of hydrolized products to biogas supported by National Science Centre Poland, (UMO-2014/13/B/ST8/04258).

Open Access This article is distributed under the terms of the Creative Commons Attribution 4.0 International License (http:// creativecommons.org/licenses/by/4.0/), which permits unrestricted use, distribution, and reproduction in any medium, provided you give appropriate credit to the original author(s) and the source, provide a link to the Creative Commons license, and indicate if changes were made.

\section{References}

1. Siles, J.A., García-García, I., Martín, A., Martín, M.A.: Integrated ozonation and biomethanization treatments of vinasse derived from ethanol manufacturing. J. Hazard. Mater. 188, 247253 (2011)

2. Bothast, R.J., Schlicher, M.A.: Biotechnological processes for conversion of corn into ethanol. Appl. Microbiol. Biotechnol. 67, 19-25 (2005)

3. Wang, P., Singh, V., Xue, H., Johnston, D.B., Rausch, K.D., Tumbleson, M.E.: Comparison of raw starch hydrolyzing enzyme with conventional liquefaction and saccharification enzymes in dry-grind corn processing. Cereal Chem. 84, 10-14 (2007)

4. Białas, W., Szymanowska, D., Grajek, W.: Fuel ethanol production from granular corn starch using Saccharomyces cerevisiae in a long term repeated SSF process with full stillage recycling. Bioresour. Technol. 101, 3126-3131 (2010)

5. Eskicioglu, C., Kennedy, K.J., Marin, J., Strehler, B.: Anaerobic digestion of whole stillage from dry-grind corn ethanol plant under mesophilic and thermophilic conditions. Bioresour. Technol. 102, 1079-1086 (2011)

6. Alkan-Ozkaynak, A., Karthikeyan, K.G.: Anaerobic digestion of thin stillage for energy recovery and water reuse in corn-ethanol plants. Bioresour. Technol. 102, 9891-9896 (2011)

7. Gao, T., Li, X.: Using thermophilic anaerobic digestate effluent to replace freshwater for bioethanol production. Bioresour. Technol. 102, 2126-2129 (2011)

8. Lin, Y., Tanaka, S.: Ethanol fermentation from biomass resources: current state and prospects. Appl. Microbiol. Biotechnol. 69, 627-642 (2006)

9. Mussatto, S.I., Dragone, G., Guimarães, P.M.R., Silva, J.P.A., Carneiro, L.M., Roberto, I.C., Vicente, A., Domingues, L., Teixeira, J.A.: Technological trends, global market, and challenges of bio-ethanol production. Biotechnol. Adv. 28, 817-830 (2010)

10. Eliasson, A., Christensson, C., Fredrik Wahlbom, C., HahnHagetrdal, B., Anaerobic xylose fermentation by recombinant Saccharomyces cerevisiae carrying XYL1, XYL2, and XKS1 in 
mineral medium chemostat cultures. Appl. Environ. Microbiol. 66, 3381-3386 (2000)

11. Wilkie, A.C., Riedesel, K.J., Owens, J.M.: Stillage characterization and anaerobic treatment of ethanol stillage from conventional and cellulosic feedstocks. Biomass Bioenergy. 19, 63-102 (2000)

12. Satyawali, Y., Balakrishnan, M.: Wastewater treatment in molasses-based alcohol distilleries for COD and color removal: a review. J. Environ. Manag. 86, 481-497 (2008)

13. Kim, J.-S., Kim, B.-G., Lee, C.-H., Kim, S.-W., Jee, H.-S., Koh, J.-H., Fane, A.G.: Development of clean technology in alcohol fermentation industry. J. Clean. Prod. 5, 263-267 (1997)

14. Tomczak-Wandzel, R., Górniaczyk, J., Mędrzycka, K.: Anaerobic treatment of distillery. 5, 11-20 (2008)

15. Chen, Y., Cheng, J.J., Creamer, K.S.: Inhibition of anaerobic digestion process: a review. Bioresour. Technol. 99, 4044-4064 (2008)

16. Gumienna, M., Lasik, M., Szambelan, K., Czarnecki, Z.: Reduction of water consumption in bioethanol production from triticale by recycling the stillage liquid phase. Acta Sci. Pol. Technol. Aliment. 10, 467-474 (2011).

17. Zhang, Q.H., Lu, X., Tang, L., Mao, Z.G., Zhang, J.H., Zhang, H.J., Sun, F.B.: A novel full recycling process through two-stage anaerobic treatment of distillery wastewater for bioethanol production from cassava. J. Hazard. Mater. 179, 635-641 (2010)

18. Sun, F., Mao, Z., Zhang, J., Zhang, H., Tang, L., Zhang, C., Zhang, J., Zhai, F.: Water-recycled cassava bioethanol production integrated with two-stage UASB treatment. Chin. J. Chem. Eng. 18, 837-842 (2010)

19. Wang, K., Zhang, J.H., Liu, P., Cao, H.S., Mao, Z.G.: Reusing a mixture of anaerobic digestion effluent and thin stillage for cassava ethanol production. J. Clean. Prod. 75, 57-63 (2014).

20. Yang, X., Wang, K., Wang, H., Zhang, J., Mao, Z.: Ethanol fermentation characteristics of recycled water by Saccharomyces cerevisiae in an integrated ethanol-methane fermentation process. Bioresour. Technol. 220, 609-614 (2016)

21. Barta, Z., Reczey, K., Zacchi, G.: Techno-economic evaluation of stillage treatment with anaerobic digestion in a softwood-toethanol process. Biotechnol. Biofuels. 3, 21 (2010)
22. Summerfelt, S.T.: Ozonation and UV irradiation. Aquac. Eng. 28, 36 (2003)

23. Shahidi, D., Roy, R., Azzouz, A.: Advances in catalytic oxidation of organic pollutants-prospects for thorough mineralization by natural clay catalysts. Appl. Catal. B Environ. 174-175, 277-292 (2015)

24. Mota, A.L.N., Albuquerque, L.F., Beltrame, L.T.C., ChiavoneFilho, O., Machulek, A. Jr., Nascimento, C.A.O.: Advanced oxidation processes and their application in the petroleum industry: a review. Braz. J. Pet. Gas. 2, 122-142 (2009)

25. Litter, M.: Introduction to photochemical advanced oxidation processes for water treatment. In: Boule, P., Bahnemann, D.W., and Robertson, P.K.J. (eds.) Environmental photochemistry part II, pp. 325-366. Springer, Berlin (2005)

26. HACH Company: Water analysis handbook. HACH Company, Loveland (2005)

27. Boczkaj, G., Kamiński, M., Przyjazny, A.: Process control and investigation of oxidation kinetics of postoxidative effluents using gas chromatography with pulsed flame photometric detection (GC-PFPD). Ind. Eng. Chem. Res. 49, 12654-12662 (2010)

28. Boczkaj, G., Przyjazny, A., Kamiński, M.: New procedures for control of industrial effluents treatment processes. Ind. Eng. Chem. Res. 56, 1503-1514 (2014)

29. Boczkaj, G., Kamiński, M.: Research on the separation properties of empty-column gas chromatography (EC-GC) and conditions for simulated distillation (SIMDIS). Anal. Bioanal. Chem. 405, 8377-8382 (2013)

30. Kamiński, M., Boczkaj, G., Głazowska, J., Hołowacz, I., Konopacka-Łyskawa D., Tomczak-Wandzel R.: Sposób wytwarzania bio- etanolu w procesie fermentacji alkoholowej, zwłaszcza z surowców odnawialnych (A process for producing bio-ethanol in the alcoholic fermentation, in particular from renewable raw materials) (2013). Polish Patent Registration, P.406014 